\title{
THE DIFFERENT INFLUENT OF THE MODEL OF INQUIRI AND DISCOVERY LEARNING TOWARD THE OUTCOME OF STUDENT LEARNING
}

\author{
Badriah Desiani 1,*, Henny Dewi Koeswanti ${ }^{2}$ \\ 1 Bachelor of International Primary Education FKIP-University of Christian Satya Wacana \\ 2 Bachelor of International Primary Education FKIP-University of Christian Satya Wacana
}

\begin{abstract}
This research aimed to find out the different learning outcome using inquiry and discovery learning model in 5th grade at Sidomukti sub-district. The subject of this research was 5th grade students at SDN Dukuh 02 as the control group and 5th grade students at SDN Mangun sari 01as experimental group. Independent variable consisted of inquiry and discovery learning model with dependent variable as the learning outcome. Data collection was conducted by using test. The technique analysis of the research result used descriptive statistic technique of Independent Sample Ttest. Based on Independent Sample T-Test which was conducted in posttest score of control group and experimental group, it resulted significance/probability of $0,038<0,05$, so that $\mathrm{HO}$ was ignored and Ha was accepted it meant that there was different average between experimental and control group. The different which was significance were in two research samples, which the average score in implementing inquiry learning model was 79,75, whereas the score of discovery learning model is 75.00. it meant that there were significance differences from the learning outcome of the students who used inquiry learning model and the students who used discovery learning model with the 8 theme of Ecosystem.
\end{abstract}

Keywords:

Inquiry, Discovery

Learning, Learning

Outcome

\section{Introduction}

The curriculum of Indonesia currently used Kurikulum Tingkat Satuan Pendidikan (KTSP) and curriculum of 2013 (K13). KTSP is operational curriculum which was conducted in education unit which are education purpose, structure and curriculum content of education unit level, educational calendar and syllabus (Arikunto\& Yuliana, 2012). The things that made the both curriculums are different was there was no competency standard which then it replaced with core competencies in curriculum 2013. As it stated by Mulyasa H. E., 2014 that things which differentiate of curriculum 13 and previous curriculum was the core competition (KI). KI here meant KI-1; spiritual attitude; KI-2: social attitude: KI-3: knowledge; ki-4: skill. Other that, the fundamental differences of curriculum 2013 pressure to the behavior or the characteristic of the students.

The forming of attitude and character of the students was obtained by controlling the students as student center with the learning activates which was used scientific approach. Scientific approach or scientific method was methodology or the way which was used to find out something (Trianto, 2010). Other than that, the scientific approach could be said as the approach which emphasize the students to be active in observing, asking, trying, reasoning, communicating and making the network (Mulyasa $\mathrm{H}$. E., 2014).

The main learning model in curriculum 2013 implementation was inquiry based learning, discovery learning, project based model learning, problem based learning model (Mulyasa H. E., 2014). The inquiry learning model was the learning model series activities which involve maximally as the ability of the students to find out systematically, logic, annalistically, so that the students could formulate their own findings with the confident (Gulo in Ambasari et al (2013). Other that, inquiry learning model is the learning model which emphasized the aspects of cognitive, affective, psychomotor equally so that the learning would be more meaningful (Sanjaya, 2006). Sanjaya (2010) explained that one of the benefit of inquiry learning was the inquiry learning was the learning model which emphasized to aspects of

* Corresponding author.

E-mail Addresses desiani.badriah@yahoo.com (Badriah Desiani), henny.dewi@staff.uksw.edu (Henny Dewi Koeswanti), 
cognitive, affective and psychomotor equally and it was considered as the more meaningful learning. According to the Ahmadi el al (2011) the learning steps of inquiry were formulating the problem, making the hypothesis, collecting the data, examining the hypothesis and drawing the conclusion.

It was not just inquiry learning, the learning model which was suggested in scientific approach was discovery learning. Discovery learning was the learning to find out something meaningful in the learning (Mulyasa, 2014). Suryosubroto (2001) stated that one of the benefits of earning discovery was, by using discovery learning, the students tried to one of research method which would develop by themselves. Then, based on Mulyasa, 2014) the step in learning discovery were stimulation, problem statement, collecting the data, data processing, verification and generalization.

From the explanations above, it can be understood that inquiry learning model was learning model which the students were required observe and search the information about the problems, whereas the discovery learning was a learning model which the students are asked to do the observation and research by themselves. Both learning models were the learning models which the students could be active in learning process. Depdikbud (2014) also explained that Discovery Learning had the same principle with inquiry. There was no different principle in the both learning. Discovery learning more emphasized the finding of concept or the principles which were unknown before. The difference between discovery and inquiry were, in discovery problem which faced by the students was like he problems that the teachers made. And in the inquiry learning, the problems were not made so that the students had to thing and use their skills to get the findings in the problem through the process of the research.

There were different learning outcomes of inquiry learning and discovery learning which were proved by the previous researcher. One of the researcher was Erni Wahyuni. She has done the experiment about "Implementation of Inquiry Learning to Increase Learning Outcomes of The Students in Science Subject about Structure and the Function from the Part of the Plants in $4^{\text {th }}$ grade in SDN Kepunduaan, subdistrict of Dukupuntang, Cirebon." The research result showed that inquiry was learning model which was better that conventional learning model. It was because the students were more active if the teachers used inquiry learning model than conventional model. Then the research which was conducted by Eriyan et al (2013) which was titled "The Different Outcome of Learning Model Using Discovery Learning Model and Inquiry Learning in Understanding the Nature of The Audio signal in SMKN 2 Surabaya" showed that there were differences of the learning outcomes between discovery learning model, inquiry learning model and conventional learning model. The students' activity that used inquiry learning model was better than the students who used discovery learning model and conventional learning model. The different outcomes of the students were caused in the class which obtained the learning of Audio signal with inquiry learning model, the students were given chance to think for finding the ideas in making the concept. The other researches also showed the different outcomes such as the research which was done by Martisari (2014) with the titled "The Different Learning Outcomes Which Used Inquiry Learning Strategic Discovery Learning Strategic in Biology Subject in VIII grade in SMP Penda Tawangmangu in 2013/2014" showed that there were different outcomes which were obtained by the students because in using discovery learning model, they got high average score. It is because both students and the teachers were active.

Things that were different from the previous research were, this research used the samples of elementary schools with the subjects of Science and the dependent variable which was observed was the learning outcomes. The purpose of the research was to find out the different influences of inquiry learning model and discovery learning model toward the learning outcomes of the students about ecosystem subject in $5^{\text {th }}$ grade in Sub-district Sidomukti Salatiga in Semester II in 2016/2017.

\section{Method}

The type of research used was quasi experimental or quasi experimental research. The research design used was Nonequivalent Control Group Design. This design was similar to the pretest-posttest control group design, only in this design the experimental or control group were not selected randomly. The experimental group and the control group were compared then given pre-test, followed by treatment, and the last was given posttest. The design of this study can be illustrated by the following table:

Table 1 (Nonequivalent Control Group Design)

\begin{tabular}{cccc}
\hline Group & Pretest t & Action & Posttest \\
\hline Control group & Y1.1 & X1 & Y1.2 \\
Experimental Group & Y2.1 & X2 & Y2.2 \\
\hline
\end{tabular}

Information : 
Y1.2: Pretest was given to the control group to determine the initial state, is there any difference between the control group and the experimental group

$Y_{2.1}$ Pretest was given to the experimental group to know the initial state, is there any difference between control group and experiment groups.

X1: Treatment for the experimental group namely learning by using inquiry model.

X2: The treatment for the control group namely learning by using discovery learning model.

Y1.2: Post-test was given to the experimental group after following the lesson by using the Inquiry learning model.

Y2.2: Post-test was given to the control group after following the learning by using the discovery learning model.

The study was conducted at SD Negeri Dukuh 02 Gugus Kanigoro and SD Negeri Mangunsari 01 Dipenogoro, Sidomukti district, Salatiga City. This research has two variables, namely independent variable $(\mathrm{X})$ and dependent variable $(\mathrm{Y})$. Independent variable (independent) was the variable that causes the change of dependent variable (dependent). In this study, the independent variable (X) was the inquiry learning model and the discovery learning model, while the dependent variable $(\mathrm{Y})$ was the learning outcomes.

The population in this study covered all 5th graders at SD Negeri Dukuh 02 and SDN Mangunsari 01. Samples taken were SDN Mangunsari 01 as experimental group (40 students) and SDN Dukuh 02 as control group (31 students). Samples used were two samples with different clusters.This is because for the Curriculum 2013 in Kota Salatiga that used the Curriculum 2013 as the whole class curriculum only the two schools above.While schools with the same cluster used Curriculum 2013 only for the 2nd and 4th grade with other than the two classes were still using KTSP Curriculum. The research for the experimental class was conducted on June $12^{\text {nd }}, 2017$, while research conducted for the control class was conducted on $13^{\text {rd }}$ June 2017.

Data collection techniques in this study used test and non-test techniques. Test technique in the form of written test and non test technique in the form of observation. The instrument used in this research was mathematics story sheet in the form of multiple choice and observation sheet consisting of teachers' activity observation sheet and students' activity observation sheet in applying inquiry learning model and discovery learning.

The Instruments were in the form of questions of multiple choices as many as 20 questions that have been tested its reliability of 0.831 . Alpha coefficient of reliability figures were in a very reliable category. The result test of validity item of the 20 questions moved between 0.329 up to 0.733 with the $\mathrm{N}$ number tested is 38 , then the rproduct moments used as reference is 0.320 with a significant level of $5 \%$.

The data analysis technique was analyzed by using descriptive technique and Independent Samples T-Test statistical technique. The Independent Samples T-Test statistical technique was performed if it met the prerequisite test: a) normality test, b) homogeneity test. Independent Samples T-Test can be used to test the significance differences of mean between the experimental and control groups.

\section{Results and Discussion}

According to the Ahmadi (2011) the learning steps of inquiry were formulating the problem, making the hypothesis, collecting the data, examining the hypothesis and drawing the conclusion. 1 . The experimental class learning process was conducted on June 12nd,2017 delivered directly by the classroom teacher with meeting as much as one time. The learning started with the teacher explained the purposes and the learning steps. Then the lesson continued by giving 2 readings about the ecosystem and students are asked to write questions related to the given reading. After that the students wrote down the questions that are on the paper that has been provided by the teacher in front of the class. Then students together with the teacher chose the question which was a problem to be solved. After selecting 5 questions, the teacher divided the students into groups consisted 5 people for each group. Students then look for hypotheses for the questions that have been agreed by the class on the paper provided by the teacher. After writing the hypothesis, the students then submitted the paper and continued to find information about the problems that occured by reading a book, asked group of friends and read articles provided by the teacher. After searching for information relating to the problem, students then reexamined the previous hypothesis and compared the answers between hypotheses and answers after searching for information. Students were then given the task of making a picture of an ecosystem, animals in it, and the food chain that occured within the ecosystem with the group. After creating the task, the students then did presentation in front of the class and explained about the task that the group got. 
Furthermore, after the presentation have finished, students with the teacher then drew conclusions about the learning that already performed.

The learning process using inquiry model made students learned actively and fun. Students are also taught to re-examine the answers that already obtained as well as students became the center of learning in which the teachers only facilitates. Overall, many students were active in learning and groups, but there were some students who still missed learning because they ere called by other teachers.

Then, based on Mulyasa, 2014) the step in learning discovery were stimulation, problem statement, collecting the data, data processing, verification and generalization.The study for control class was conducted on 13 June 2017 with a one-time meeting and presented by the researcher. The learning process of the control class began with the teacher explained the learning objectives and the learning steps that would be implemented. The teacher provided stories and pictures as an introduction to the learning process that was followed by a stimulus in the form of questions given by the teacher as a problem to be solved by the students. After that students identified the issues to be solved and sought information by reading a book or discussing with a friend and asking the teacher. Furthermore, students did dataprocessing andsorting information from books and articles provided by teachers in accordance to the given problem. Re-checking data obtained by students was done by asking the teacher. Teachers together with students then did the question and answer and made conclusions from the given material.

The learning process using discovery learning model made students learning actively though there were some students who were still questioning about the terms in the learning materials that were not understood.

\section{Normality Test Results}

Normality test was done to determine if the data population was normally distributed or not. This study used the results of normality test by looking at the results of kolmogrov-smimov. The data population was said to be normally distributed if the significance was greater than $5 \%$ or 0.05 . If the signification was below $5 \%$ or 0.05 then the data was declared to be abnormally distributed. Based on the output results of the normality data, the control class significance for the pretest result was 0.41 and the experimental class was 0.40 . These data showedthat the signification result was greater than 0.05 and the data was declared as a normal distributed pretest. While the significance of the control class for the postest result was 0.173 and the experimental class was 0.133 . It can be concluded that the distribution of post control group data and the experimental group was from a normally distributed population.

\section{Homogentity Test Results}

Homogeneity test was conducted to find out whether the data from each sample group had the same or different variant. Homogeneity criteria of the experimental and control class ere if the significance of the data variant> 0.05 then the data was declared homogeneous or the same between the two data. When formulated a HO hypothesis was the variance of the data in each group were similar (homogeneous) and Hawas the variance of the data in each group we not similar (not homogeneous), then it can be decided if the probability <value $\alpha(0.05) \mathrm{H} 0$ rejected and Ha accepted, if the probability> value $\alpha$ (0.05) H0rejected and Ha accepted.

Table 2 Pretest Homogeneity Test Experiment and Control Class
Test of Homogeneity of Variances
Nilai Pretest Kontrol Eksperimen
\begin{tabular}{ccccc}
\hline Levene Statistic & df1 & df2 & Sig. \\
\hline .595 & 1 & 69 & .443 \\
\hline
\end{tabular}

Based on the Test of Homogeneity of Variances the significance / probability of the final measurement value showed the number 0.443 . If it was formulated a hypothesis $\mathrm{H} 0$ was data variance in each group was the same (homogeneous) and Ha was the data variance in each group was not equal (not homogeneous), it can be decided if the probability <value $\alpha(0.05) \mathrm{H} 0$ was rejected, otherwise $\mathrm{H} 0$ was accepted. Since the significance / probability value of the data was 0.443 , where $0.443>0.05$ then $\mathrm{H} 0$ was accepted. That means it can be said that the post-test scores of the control group and the experimental group were homogeneous. 
Table 3 Posttest Homogeneity Test Experiment and Control Class Test of Homogeneity of Variances NilaiPosttestKontrolEksperimen

\begin{tabular}{cccc}
\hline Levene Statistic & $\mathrm{df} 1$ & $\mathrm{df} 2$ & Sig. \\
2.676 & 1 & 69 & .106 \\
\hline
\end{tabular}

Based on the Test of Homogeneity of Variances the significance / probability of the final measurement value showed the number 0.106. If it was formulated a hypothesis HO was data variance in each group was the same (homogeneous) and Ha was the data variance in each group was not equal (not homogeneous), it can be decided if the probability <value $\alpha$ (0.05) H0 was rejected, otherwise H0 was accepted. Since the significance / probability value of the data was 0.106 , where $0.106>0.05$ then H0 was accepted. That means it can be said that the post-test scores of the control group and the experimental group were homogeneous.

\section{Hypothesis}

Research result conducted after the stdents given the treatment with both variables, then the Ttest will be done in order to determine whether there was an average difference between the two samples that were not related. So, it can find out whether there were differences in learning outcomes by using inquiry learning model for experimental class and discovery learning for control class. Independent sample t-test using two-samples test that will see the results of significance on the sig. (2-tailed). Here are the test results of independent sample t-test:

$\mathrm{H} 0$ accepted if the significance $>0.05$.

$\mathrm{H} 0$ rejected if the significance $<0.05$.

H0: $\mu 1=\mu 2$ This means that there was no significant difference in the application of inquiry learning model and discovery learning to students learning outcomes with the theme ecosystem of 5th grade Sidomukti district Salatiga Semester II Lesson Year 2016/2017.

Ha: $\mu 1 \neq \mu 2$ This means that there was a significant difference in the application of inquiry learning model and discovery learning to students learning outcomes with the theme ecosystem of 5th grade Sidomukti district Salatiga Semester II Lesson Year 2016/2017. Below is the output of independent sample T-test of experiment class and control class:

Table 4. Independent Sample T-Test

\begin{tabular}{|c|c|c|c|c|c|c|c|c|c|c|}
\hline \multicolumn{11}{|c|}{ Independent Samples Test } \\
\hline \multirow{2}{*}{\multicolumn{6}{|c|}{$\begin{array}{c}\text { Levene's Test for } \\
\text { Equality of Variances }\end{array}$}} & \multirow{2}{*}{\multicolumn{3}{|c|}{ t-test for Equality of Means }} & & \\
\hline & & & & & & & & & & \\
\hline & & \multirow[b]{2}{*}{$\mathrm{F}$} & \multirow[b]{2}{*}{ Sig. } & \multirow[b]{2}{*}{$\mathrm{t}$} & \multirow[b]{2}{*}{$\mathrm{df}$} & \multirow{2}{*}{$\begin{array}{l}\text { Sig. (2- } \\
\text { tailed) }\end{array}$} & \multirow{2}{*}{$\begin{array}{c}\text { Mean } \\
\text { Differenc } \\
\mathrm{e}\end{array}$} & \multirow{2}{*}{$\begin{array}{c}\text { Std. Error } \\
\text { Differenc } \\
\text { e }\end{array}$} & \multicolumn{2}{|c|}{$\begin{array}{l}\text { 95\% Confidence } \\
\text { Interval of the } \\
\text { Difference }\end{array}$} \\
\hline & & & & & & & & & Lower & Upper \\
\hline \multirow[t]{2}{*}{$\begin{array}{c}\text { Postes } \\
\text { Kontrol } \\
\text { Eksperi } \\
\text { men }\end{array}$} & $\begin{array}{l}\text { Equal } \\
\text { variance } \\
\mathrm{s} \\
\text { assumed }\end{array}$ & 4.489 & .038 & 2.112 & 69 & .038 & 4.750 & 2.249 & .263 & 9.237 \\
\hline & $\begin{array}{l}\text { Equal } \\
\text { variance } \\
\text { s not } \\
\text { assumed }\end{array}$ & & & 2.188 & 68.955 & .032 & 4.750 & 2.171 & .419 & 9.081 \\
\hline
\end{tabular}

Based on the test of Independent Samples T-Test conducted on post-test score of the control group and experimental group were obtained the result of significance / probability (2-tailed) 0,038 or $<0,05$ then $\mathrm{H} 0$ rejected and $\mathrm{Ha}$ accepted. This means that there was significant differences in the application of inquiry learning model and discovery learning to the students learning outcomes with the theme ecosystem of 5th grade Sidomukti district Salatiga Semester II Lesson Year 2016/2017.

Descriptive analysis of experiment and control class 
Table 5 Descriptive Pre-test Score of Experimental and Control Classes

\begin{tabular}{cccccc}
\hline & Groups & N & Mean & Std. Deviation & Std. Error Mean \\
\hline $\begin{array}{c}\text { Pre-test Control } \\
\begin{array}{c}\text { Pre-test } \\
\text { Experiment }\end{array}\end{array}$ & 1 & 31 & 54.35 & 15.316 & 2.751 \\
\hline
\end{tabular}

Based on the output result of descriptive analysis of the mean of experiment and control class above, with different amount of $\mathrm{N}$. $\mathrm{N}$ for control class as many as 31 people and $\mathrm{N}$ for experiment class as many as 40 people. There was not much difference in the average number of pretest score for both the control class and the experimental class. The average number of pretest score controls was 54.35 with a standard deviation of 15,316. While the average pretest score of experiments was 54.25 with a standard deviation of 13,566 . The above showed that the initial ability of learners between the control and experimental classes were not much different which was shown by the pretest score before treatment was given.

Table 6 Descriptive Post-test Score of Experiment and Control Classes Group Statistics

\begin{tabular}{cccccc}
\hline & Group & $\mathrm{N}$ & Mean & $\begin{array}{c}\text { Std. } \\
\text { Deviation }\end{array}$ & $\begin{array}{c}\text { Std. Error } \\
\text { Mean }\end{array}$ \\
\hline Post-test control & 1 & 31 & 75.00 & 7.853 & 1.410 \\
Post-test Experiment & 2 & 40 & 79.75 & 10.436 & 1.650 \\
\hline
\end{tabular}

Based on the above table, it can be seen that there were differences in mean score of post-test control group and experimental group. The difference can be determined from the difference between the mean scores of control and the experimental group. In the post-test results, the score difference between the control group and the experimental group was 4.75 , where the mean score of the experimental group was superior than the mean score of control group.

This study has several stages of activities conducted to the control class as well as the experimental class. Stages of such activities include pre-test, treatment / treatment, and post-test. Pre-test stages did just before the teacher was giving treatment to the students, while post-test did after the treatment. Pre-test and treatments and post-testexperiment class were conducted on June 12, 2017. As for the control class was conducted on June 13, 2017. The allocation of time required for the experimental and contraction classes were 2x35 minutes for a single meeting. The pretest given aimed to determine the initial ability of the learner before treatmentwas given, whereas the post-test was given to the learner to know whether there was difference between before and after being treated to the learners' learning outcomes.

The result of the experimental class analysis and control analysis above showed that there was a significant difference to the students learning outcomes with theme 8 that was ecosystem that used inquiry learning model as experiment class and discovery learning as control class.

A significant difference can be seen from the test ofindependent sample t-test for the sig. (2tailed) value smaller than 0.05 ie 0.038 . The significance value which smaller than 0.05 indicated that $\mathrm{H0}$ rejected and $\mathrm{Ha}$ accepted which means there was significant difference in the application of inquiry learning model and discovery learning to the students learning outcomes with the theme of ecosystem 5th grade Sidomukti district Salatiga Semester II Lesson Year 2016/2017.

The finding that there was a significant difference in the application of inquiry learning model compared with the learning discovery learning model in the learners' learning outcomes was supported by the mean difference of each group. The mean score on the application of inquiry learning model was 79.75, while the mean score on the application of discovery learning model was 75.00. This proved that the inquiry learning model has a different and higher impact than the discovery learning model.

The results of the above study can be understood, because inquiry learning model has advantages which are able to form and develop "self concept" in learners, so that learners can understand the basic concepts and ideas better and helped and used memory and transfer on a new learning situation. The steps of learning inquiry model were: 1) formulated the problem, 2) developed the hypothesis, 3) collected the data, 4) tested the hypothesis, 5) formulated the conclusion.

The following was a description of the learning step of the inquiry learning model: the first step, the learning began with the teacher explained the purposes and the learning steps. Then the lesson continued by giving 2 readings about the ecosystem and students were asked to write questions related to 
the given reading.. The second step, after which students wrote the questions on the paper that has been provided by the teacher in front of the class. Then students together with the teacher chose the question which was a problem to be solved. After selecting 5 questions, the teacher divided the students into groups consisted of 5 people of each group. The third step, students then look for hypotheses for the questions that have been agreed by the class on the paper provided by the teacher. After writing the hypothesis, the students then submitted the paper and continued to find information about the problems that occured by reading a book, asked group of friends and read articles provided by the teacher. The fourth step was the students then re-examined the previous hypothesis and compared the answers between hypotheses and answers after searching for information. Students were then given the task of making a picture of an ecosystem, animals in it, and the food chain that occured within the ecosystem with the group. After creating the task, the students then did presentation in front of the class and explained about the task that the group got. The fifth step was the students with the teacher then drew conclusions about the learning that already performed.

\section{Conclusion}

Based on result of data analysis of research result and discussion about difference influence of application of inquiry learning model and discovery learning to the learning outcomes result, it can be concluded that: descriptively the difference of learning outcomes theme 8 ecosystem of experimental class relative better than control class learning outcomes. This can be seen from the mean score of experimental class using better inquiry study model that was equal to 79.75, while the mean score of control class were 75.00. This was also supported by hypothesis test results that showed $\mathrm{H}_{0}$ was rejected and $\mathrm{H}_{\mathrm{a}}$ was accepted. Based on the test ofIndependent Sample T-Test that has been done on post-test score of control group and experimental group obtained the result of significance $0,038<0,05$, then $\mathrm{H}_{0}$ was rejected and $\mathrm{H}_{\mathrm{a}}$ was accepted. This means that there were significant differences in the influence of inquiry learning model and discovery learning on the learning outcomes of learners with the theme of ecosystem 5th grade Sidomukti district Salatiga Semester II Year Lesson 2016/2017.

\section{Refferences}

Chatib, M. (2013). Gurunya Manusia: Menjadikan Semua Anak Istemewa dan Semua Anak Juara. Bandung: Kaifa.

Daryanto, T. (2012). Konsep Pembelajaran Kreatif. Yogyakarta: Penerbit Gava Media.

Eriyan Hermawan Dkk. (Perbedaan Hasil Belajar Menggunakan Model Guided Discovery Dengan Model Inquiry Pada Pelajaran Memahami Sifat Dasar Sinyal Audio Di Smk N 2 Surabaya) Diunduh Di Alamathttp://goo.gl/5e6nwI

Erni Wahyuni (2012). Penerapan Model Pembelajaran Inkuiri Dalam Meningkatkan Hasil Belajar Peserta didik Pada Pelajaran IPA Pokok Bahasan Struktur Dan Fungsi Bagian-Bagian Tumbuhan Di Kelas IV SDN Kepunduan Kecamatan Dukupuntang Kabupaten Cirebon. Diunduh dialamathttps://goo.gl/iR87so

Iif Khoiri Ahmadi, d. (2011). Strategi Pembelajaran Berorientasi KTSP. Jakarta: Pt. Prestasi Pustakaraya.

Diana Karitas, Hery Kusumawati, Fransiska Susilawati, Ari Subekti dan Maryanto. (2014). Ekosistem Buku tematik Terpadu Kurikulum 2013 Tema 8. Jakarta: Kementrian Pendidikan dan Kebudayaan.

Martisari, I. (2014, Maret 3). Perbedaan Hasil Belajar Menggunakan Strategi Pembelajaran Inkuiri dan Discovery dalam Mata Pelajaran Biologi Siswa Kelas VIII di SMP Penda Tawangmangu Tahun Ajaran 2013 - 2014. Surakarta, Jawa Tengah, Indonesia.

Prof. Dr. H. E. Mulyasa, M. (2014). Guru dalam Implementasi Kurikulum 2013. Bandung: PT Remaja Rosdakarya Offset.

Prof. Dr. Suharsimi Arikunto \& Lia Yuliana, M.Pd. (2012). Manajemen Pendidikan. Yogyakarta: Aditya Media Yogyakarta.

Sani, R. A. (2014). Inovasi Pembelajaran. Jakarta: Bumi Aksara. 
Sanjaya, W. (2010). Strategi Pembelajaran Berorientasi. Standar Proses Pendidikan. Jakarta: Kencana Prenada Media Group.

Suryosubroto. (2002). Proses Belajar Mengajar di Sekolah. Jakarta: Rineka Cipta.

Trianto, M. (2010). model pembelajaran terpadu. jakarta: PT Bumi Aksara. 